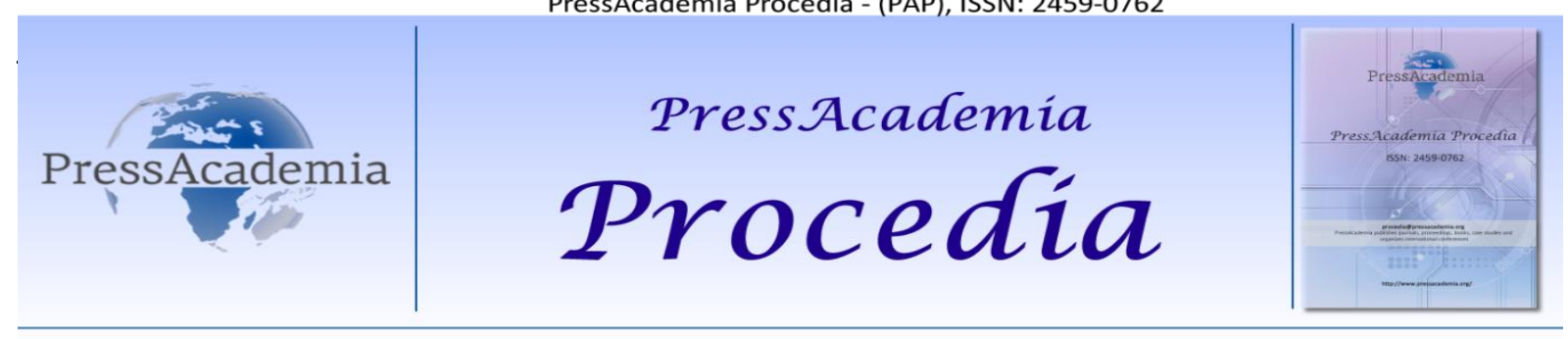

Global Business Research Congress (GBRC), May 24-25, 2017, Istanbul, Turkey.

\title{
PREFERIBILITY COMPARISON BETWEEN SOCIAL ENTERPRISES AND NON-GOVERNMENTAL ORGANIZATIONS IN TURKEY
}

\author{
DOI: 10.17261/Pressacademia.2017.676 \\ PAP-GBRC-V.3-2017(103)-p.946-951
}

\section{Pelin Surmeli}

Koç University, Rumelifeneri Yolu, İstanbul, Turkey. psurmeli@ku.edu.tr

\section{To cite this document}

Srrmeli, P.. (2017). Preferibility comparison between social enterprises and non governmental organizations in Turkey. PressAcademia Procedia (PAP), V.3, p.946-951.

Permemant link to this document: http://doi.org/10.17261/Pressacademia.2017.676

Copyright: Published by PressAcademia and limited licenced re-use rights only.

\begin{abstract}
Projects based on solving a social problem create social changes, which is called social impact. Non-governmental organizations and social enterprises both create social impacts. This study examines if social enterprises can be an alternative for NGO's in order to create social impact, and why. According to the results, social enterprises might be defined as the alternative for NGO's. Also the importa nce of financial and governmental support to social enterprises in order to create awareness on consumers and encourage potential social entrepreneurs would be examined. In this study, convenience sampling method will be used. Data will be collected via survey by face to face, and will be examined on Excel.
\end{abstract}

Keywords: Social enterprise, ngo, social impact, philanthropy, social problem

JEL Codes: L31, M14, P31

\section{INTRODUCTION}

Non-governmental organizations are non-profit autonomous organizations based on volunteering. Social enterprises are companies that contribute to a social problem by either a certain percentage of their profit or by the virtue of their business model. Projects based on solving a social problem create social changes, which is called social impact. Non-governmental organizations and social enterprises both create social impacts.

The level and sustainability of a social impact created by non-governmental organizations or social enterprises are directly related with their financial power. This study examines community tendency to support non-governmental organizations and social enterprises in Turkey. The study compares donation to a NGO and consumption from a social enterprises, both result a social impact.

This study examines public preference of NGOs and social enterprises, the reason of these preferences and if sociel enterprises can be an alternative for NGOs. People's motivation to support NGOs and social enterprises are also examined.

According to the results, social enterprises might be defined as the alternative for NGO's. In this study, convenience sampling method will be used. Data will be collected via survey by face to face, and will be examined on Excel. 


\section{LITERATURE REVIEW}

\subsection{Philanthropy: Social Enterprises and NGO's}

According to the Merriam-Webster dictionary, philanthropy is defined as "an act or gift done or made for humanitarian purposes". The definition includes not only 'gifts' that are the givings without wanting anything in return, but also acts. Robert Payton and Michael Moody also highlight that philanthropy is not only about actions and doing things, but also about ideas and values as well.(Payton and Moody, 2008:4) Hence, the motivation of doing something for humanitarian purposes is the basics of all philanthropic actions. Today, philanthropic actions can be defined in a broad range of activities; such as NGO donations, volunteerings, religious givings, individual donations etc.

Within past decades, a new business model called 'social enterprise' emerged, and today social enterprises are legally defined institutions in various countries. Social enterprises are defined by European Union as "an operator in the social economy whose main objective is to have a social impact rather than make a profit for their owners or shareholders." (European Eunion 2001:Article2). According to the European Commission's, social enterprises has to have the following characteristics: "the social objective was the reason for developing innovative activities; profits were mainly invested in achieving this social objective; and the organisation and ownership used participatory principles aiming at social justice." (European Commision 2014:19) Based on its social justice characteristics and social impact motivation, social enterprises are another component of philanthropic actions.

According to Anna-Karin Lindbloom, there is no generally accepted definition of NGO in international law.(Lindblom 2005:36) However, one of the main basic characteristics of NGO's that they are non-profit organizations. Different from social enterprises, Non-Governmental Organizations (NGO) has no interest to make profits, nor they have a business model; main sources of their support relies on donations and volunteering; and participation of NGO activities is considered as philanthropic.

\subsection{Social Impact}

Social impact is defined as "the effect of an activity on the social fabric of the community and well-being of the individuals and families."(BusinessDictionary: social impact) Hence, all philanthropic activities create social impact. Social impact is an important indicator of the success of an activity. People can create social impact by trading (shoping) from social enterprises, which also satisfies their needs. On the other hand, people can create social impact by donating to NGO's, which requires no favor in return. This study indicates the NGO or social enterprise preferences of the public in order to maximize the social impact, in other words, people's participation to the solution of a problem.

\subsection{Philanthropy in Turkey}

Philanthropic activities in modern Turkey have historic roots. According to Murat Çizikça, philanthropic activities are shaped by three main tradition: Roman/Byzantine influence, Ottoman/Turkish foundations and Western influence. (Çizikça, 2006:29) Ottoman 'Waqf' (foundation) system, which is based on İslamic values and religious context, continuous its philanthropic impacts in Turkey today. (Çizikça 2006:40) According to Ali Çarkoğlu, the main motivation of charity in Turkey is religious obligations by $32.5 \%$, followed by traditions and customs by $26.3 \%$. (Çarkoğlu 2006:100) Despite of that, Çarkoğlu claims that in highly conservative Muslim country, such as Turkey, religiously motivated giving is not as much as expected.(Çarkoğlu 2006:128) Çarkoğlu noted that the main reason of this is noted that people do not attribute such responsibilities as philanthropy, but thinks it is state's duty to perform. According to his survey, people see the main responsible for helping the needy is the state by $38.2 \%$, followed by wealthy people by $30.9 \% .20 .9 \%$ of the participants think that all citizens are responsibly, and 5.4\% of the participants think that it's NGO's responsibility. (Çarkoğlu 2006:99) Overall, the total giving in Turkey is less than 1\% of the household income. (Çarkoğlu 2006:128) However, according to Filiz Bikmen, the practices of corporate philanthropy in Turkey is increasing. (Bikmen, 2003). Hence, the number of organisations that work to create or increase social impact is increasing, such as corporate social responsibilities or social enterprises. This situation helps people to create social impact ialternative indirect ways.

\section{DATA AND METHODOLOGY}

Based on the given fact that supports to NGO's is lower than expected for social welfare expectations from the state, philanthropic activities in Turkey needs new trends to gain more support. The aim of this study is to investigate the preferability aspects of NGO and social enterprises; and investigate whether social enterprises can be an alternative tool to create social impact rather than NGO's. This is an exploratory research.

The surveys were conducted in a shopping mall in central istanbul at a weekend by convenience sampling method. Respondents are over the age of 18 , from different income groups, different education level and different professions. The 
data for the study is collected by surveys by the researcher face to face. In the survey, consumers were targeted and 80 respondents participated to the survey.

The survey has 4 parts. The first part includes demographic questions, such as gender, age, education level, professions and income. The second part of the survey has questions about NGO's, along with a definition and an example.

- $\quad$ Are you donating to any NGO?

- If so, is it periodically?

- Approximately how much you donate for a month?

- If not, why?

The third part of the survey has questions about social enterprises, along with a definition and an example.

- Have you heard the term 'social enterprise' before?

- Did you ever support any social enterprise by choosing them for your consumptions?

- From now on, do you consider to choose social enterprises for your consumptions to support them?

- If your answer is 'depends', please choose the conditions.

The fourth part of the survey has comparison questions.

- Do you consider to donate to an NGO in the future?

- Do you consider to choose social enterprises for your consumption in the future?

- Both NGO and social enterprises creates social impact against a social problem. Based on your consumption preferences, which one do you prefer?

In this study, Microsoft Excel is used.

\section{FINDINGS AND DISCUSSIONS}

$56 \%$ of respondents are women and $44 \%$ of respondents are men. $22.5 \%$ is under 25 years old, $55 \%$ is between $25-34$ years old, $6.25 \%$ is between $35-44$ years old, $10 \%$ is between $45-54$ years old and $6.25 \%$ is between $55-64$ years old. $7.5 \%$ of respondents are high school graduate, $62.5 \%$ is graduate and $30 \%$ is post graduate. 
Table 1: Demographics

\begin{tabular}{|l|l|l|l|}
\hline \multicolumn{2}{|l|}{} & $f$ & $\%$ \\
\hline \multirow{5}{*}{ Gender } & Women & 56 & 70 \\
\cline { 2 - 4 } & Men & 44 & 30 \\
\hline \multirow{5}{*}{ Age } & Under 25 & 18 & 22.5 \\
\cline { 2 - 4 } & $25-34$ & 44 & 55 \\
\cline { 2 - 4 } & $35-44$ & 5 & 6.25 \\
\cline { 2 - 4 } & $45-54$ & 8 & 10 \\
\cline { 2 - 4 } & 55-64 & 5 & 6.25 \\
\cline { 2 - 4 } & Over 65 & 0 & 0 \\
\hline \multirow{5}{*}{ Education Level } & High School & 6 & 7.5 \\
\cline { 2 - 4 } & Undergraduate & 0 & 0 \\
\cline { 2 - 4 } & Graduate & 50 & 62.5 \\
\cline { 2 - 4 } & Post Graduate & 24 & 30.0 \\
\hline \multirow{5}{*}{} & 80 & 100 \\
\hline
\end{tabular}

When they asked about their NGO or social enterprise preference, $76.25 \%$ of respondents prefer social enterprises, and $23.75 \%$ of respondents prefer NGOs in total. $88 \%$ of under 25 years old respondents prefers social enterprises, $75 \%$ of $25-34$ years old respondents prefer social enterprises, $100 \%$ of $35-44$ years old respondents prefer social enterprises, $50 \%$ of 45 54 years old respondents prefer social enterprises and $60 \%$ of $55-64$ years old respondents prefer social enterprises over NGO's.

Table 2: NGO and Social Enterprise Preferences According to Ages

\begin{tabular}{|l|c|c|c|c|c|}
\hline Age & Total & NGO & \% for NGO & Social Enterprise & \% for Social Enterprise \\
\hline Under 25 & 18 & 2 & 12 & 16 & 88 \\
\hline $25-34$ & 44 & 11 & 25 & 33 & 100 \\
\hline $35-44$ & 5 & 0 & 0 & 5 & 50 \\
\hline $45-54$ & 8 & 4 & 50 & 4 & 60 \\
\hline $55-64$ & 5 & 2 & 40 & 0 & 0 \\
\hline Over 65 & 0 & 0 & 0 & 61 & 76.25 \\
\hline Total & 80 & 19 & 23.75 & & 3 \\
\hline
\end{tabular}


Among 12 people who never heard about the concept of 'social enterprise', 50\% of them claims that they will choose social enterprises for their consumptions in the future, and $50 \%$ of them claims that they will choose social enterprises for their consumptions in the future conditionally. By $33 \%$, the most chosen condition is that "If I am convinced that the social enterprise has an impact on the solution of targeted social problem". By $22 \%$, the second most chosen condition is that "availability of the service or product of the social enterprise". The following answers are, by $17 \%$, "If I am interested in about the social problem that the social enterprise is targeted", by $16 \%$ "price of the service or product of the social enterprise", by $6 \%$ "my need for the service or product of the social enterprise" and $6 \%$ "recognition of the social enterprise". Hence, have never heard about social enterprises, the transparency and corporate communication of social enterprises are very important in order to convince consumers that their consumption preferences has a social impact advantage with a social enterprise.

Among 68 people who have heard about social enterprises, 50\% of them claims that they will choose social enterprises for their consumptions in the future, and $50 \%$ of them claims that they will choose social enterprises for their consumptions in the future conditionally. By $28 \%$, the most chosen condition is that "If I am convinced that the social enterprise has an impact on the solution of targeted social problem". By $20 \%$ the second most chosen condition is that "my need for the service or product of the social enterprise". By $19 \%$ "If I am interested in about the social problem that the social enterprise is targeted", by $16 \%$ "price of the service or product of the social enterprise", by $14 \%$ "availability of the service or product of the social enterprise", by $3 \%$ "my loyalty to the brand that I am currently choosing". Hence, for the people who have heard about social enterprises before, the transparency and corporate communication of social enterprises are still the most important condition for choosing social enterprises for their consumption.

There are 54 people who do not donate to NGOs. $57 \%$ of them (31 people) claims that the financial reasons. Among this 54 people who do not donate to NGOs, $51.8 \%$ ( 28 people) of them claims that they will consider to consume from social enterprises, and $48.2 \%$ ( 26 people) of them claims that they will consider to consume from social enterprises conditionally. The most chosen condition is "If I am convinced that the social enterprise has an impact on the solution of targeted social problem" by $23 \%$. The second most chosen conditions are "my need for the service or product of the social enterprise" and "If I am interested in about the social problem that the social enterprise is targeted" by $18 \%$. At the third, "price of the service or product of the social enterprise" and "availability of the service or product of the social enterprise" by $15 \%$. At last, by $5.5 \%$, "my loyalty to the brand that I am currently choosing" and "recognition of the social enterprise". Hence, among all of the people who do not donate to NGOs for financial reasons, people are eager to choose social enterprises for their consumption either unconditional or conditional. Again, the most important condition appears to be the persuasiveness of a social enterprise in terms of their social impact.

\section{CONCLUSION}

According to the survey, younger generations tend to consume from social enterprises rather than donate NGOs. This shows us the big potential of youth in given economic conditions. Creating awareness on social problems, increasing the knowledge about social impact and social enterprises, encouraging youth to create innovative ways to solve social problems, financially support them to create their own business model and sharing cumulative know-how of big corporations and NGOs with youth to strengthen them in solution creating process might help to create bigger social impact in the future. Today, incubation centers for young entrepreneurs are widely spreaded in the country, with cooperations with national and international companies, NGOs and academics. However, social entrepreneurship concepts is slightly newer, and needs to be focused more. As their corporate social responsibility projects, some companies started to create awareness on 'social enterprise' concept and support social entrepreneurs, such as Buluşum Platformu project by Boyner Holding. These projects helps public to get used to the concept of social entrepreneurship, and get the advantage to create their own business model for the solution of a social problem. For future researches the reason why younger generation choose social enterprises can be examined. This will allow us to understand the motivations of the youth, and how can we motivate them more in order to support social enterprise concept.

Regardless from age, people who do not donate to NGOs for financial reasons tend to consume from social enterprises. This group of people are the ones that do not create any social impact in terms of NGOs and social enterprises. In given conditions, choosing social enterprises for their consumption means they will start creating social impact. Hence, even for the people who do not have enough money to donate, changing their consumption preferences will simply helps to create social impact, and they might be a part of the solution of a social problem. Overall, the people who participate to a solution process in the society increase.

To sum up, social enterprises can be an alternative tool to increase social impact and philanthropic actions within the society for both financially limited individuals and the youths. 


\section{REFERENCES}

Bikmen, Filiz.(2003). Corporate Philanthropy in Turkey: Building on Tradition, Adopting to Change. TÜSEV. Pp.1-3.

Çarkoğlu, Ali.(2006). Trends in Individual Giving and Foundation Practices. Philantrophy in Turkey: Citizens, Foundations and Pursuit of Social Justice, TÜSEV, İstanbul. Pp.96-142.

Çizikça, Murat. (2006).Economic Dimansions of Foudnations in the Ottoman Era.Philantrophy in Turkey: Citizens, Foundations and Pursuit of Social Justice, TÜSEV,istanbul. Pp.29-42

European Commision. (2014). Social Innovation: A Decade of Changes. Pp.19

European Union. (2011). Proposed Definition: Article 2,Definitions, For the purpose of this Regulation: (a)

Lindblom, Anna-Karin.(2005). Non-Governmental Organisations in International Law. Cambridge University Press. Edinburg, UK. Pp.36

Payton, Robert L., Michael P. Moody.(2008) Understanding Philantropy: Its Meaning and Mission. Indıan University Press, Bloomington, USA. Pp.4

"Philanthropy." Merriam-Webster.com. Merriam-Webster, n.d. Web. 9 May 2017.

"social impact" BusinessDictionary.com. WebFinance, Inc. May 05, 2017 